\title{
Experimental ostreid herpesvirus 1 infection of the Pacific oyster Crassostrea gigas: Kinetics of virus DNA detection by q-PCR in seawater and in oyster samples
}

\author{
D. Schikorski ${ }^{a}$, N. Faury ${ }^{a}$, J.F. Pepin ${ }^{a}$, D. Saulnier ${ }^{a}$, D. Tourbiez ${ }^{a}$ and T. Renault ${ }^{a}{ }^{*}$ \\ a Institut Français de Recherche pour l'Exploitation de la Mer (IFREMER), Laboratoire de Génétique et \\ Pathologie (LGP), 17390 La Tremblade, France
}

\author{
* Corresponding author: T. Renault, Tel.: +33 5467626 10; fax: +33 5467626 11, email address : \\ trenault@ifremer.fr
}

\begin{abstract}
:
Herpes- and herpes-like viruses are known to infect a wide range of bivalve mollusc species throughout the world. Abnormal summer mortalities associated to the detection of ostreid herpesvirus 1 (OsHV-1) have been currently reported in France among larvae and spat of the Pacific cupped oyster Crassostrea gigas.

In the present work, we have developed an experimental protocol of horizontal transmission based on the cohabitation between healthy and experimentally infected oysters. Through a cohabitation trial, the kinetics of OsHV-1 detection in different oyster organs and seawater samples were investigated and characterized for the first time using real time quantitative PCR.
\end{abstract}

Keywords: Ostreid herpesvirus 1; Cupped Pacific oyster; Crassostrea gigas; Experimental infection; Kinetic viral DNA quantification 


\section{Introduction}

Infections by herpes- or herpes-like viruses have been reported in various marine mollusc species throughout the world. Such viruses were reported in USA (Farley, 1972; Friedman et al., 2005), New Zealand (Hine, 1992), Australia (Hine and Thorne, 1997), Mexico (VasquezYeomans et al., 2004), in Asian countries (Moss et al., 2007) and France. The first description of a virus morphologically similar to members of the Herpesviridae family was reported by Farley et al. (1972) in eastern oysters Crassostrea virginica. Herpes-like virus infections have then been reported in other bivalve species, including the Pacific oyster Crassostrea gigas (Arzul et al., 2001b,c; Hine, 1992; Nicolas et al., 1992; Renault et al., 1994), the European flat oyster Ostrea edulis (Arzul et al., 2001b,c; Comps and Cochennec, 1993; Renault et al., 2000b), the Chilean oyster Tiostrea chilentis (Hine et al., 1998), the Portuguese oyster Crassostrea angulata (Arzul et al., 2001b), the Suminoe oyster Crassostrea rivularis (Arzul et al., 2001b,c), the Manila clam Ruditapes philippinarum (Arzul et al., 2001c; Renault and Arzul, 2001; Renault et al., 2001), the carpet shell clam $R$. decussatus (Arzul et al., 2001c; Renault and Arzul, 2001), and the French scallop Pecten maximus (Arzul et al., 2001a). Herpes-like infections have also been described recently in different abalone species Haliotis laevigata, Haliotis rubra, and Haliotis diversicolor (Chang et al., 2005; Hooper et al., 2007; Tan et al., 2008).

Since 1991, episodic herpes-like virus infections have been reported in France in Crassotrea gigas spat and juveniles (Renault, 1998). These virus infections are mostly evidenced during the summer period, concomitantly with a rapid increase of seawater temperature (Garcia et al., unpublished data). They are generally associated with high mortality rates reaching up to 80\% (Renault et al., 1994, 1995). Herpes-like viruses have also been detected in adult oysters (Arzul et al., 2002; Hine and Thorne, 1997). However, adults appear less sensitive to the disease than spat. This may be explained in part by the existence of a higher antiviral immune response in adults. Previous studies have presumed the presence of hypothetical antiviral molecules in Pacific oyster haemolymph (Olicard et al., 2005a,b).

A purification protocol established in order to isolate viral particles from infected $C$. gigas larvae allowed the characterization of the complete genome sequence and the nucleocapsid reconstructed structure of the virus (Davison et al., 2005; Le Deuff and Renault, 1999). This virus was classified as the sole member of the genus Ostreavirus (family Malacoherpesviridae, order Herpesvirales) and was named ostreid herpesvirus 1 (OsHV-1) (Arzul et al., 2002; Davison, 2002; Davison et al., 2005, 2009; Minson et al., 2000).

The economical importance of $C$. gigas oyster aquaculture has contributed to the development of specific and sensitive diagnostic tools, including polymerase chain reaction (PCR) (Renault et al., 2000a; Renault and Lipart, 1998), in situ hybridization (ISH) (Lipart and Renault, 2002; Renault and Lipart, 1998), immunohistochemistry (Le Deuff et al., 1995), and recently real-time PCR (Pepin et al., 2008). These techniques allowed to keep a watch on the detection of the viral infection in the natural environment through epidemiological investigations. Furthermore, the infectivity of OsHV-1 was confirmed towards younger stages of C. gigas through experimental trials conducted in laboratory conditions. It was first demonstrated that axenic healthy larvae could be infected by contact with filtered suspensions of ground infected larvae (Arzul et al., 2001b,c; Le Deuff et al., 1995, 1996).

In 2008, in order to explore the causes of massive mortality outbreaks affecting French $C$. gigas spat, experimental infection trials were carried out (Schikorski et al., submitted). The intramuscular injection of viral suspensions prepared from naturally infected fresh oysters induced high mortality rates reaching up to $80 \%$ in 3 days in healthy 1-year-old oysters. The capacity to obtain OsHV-1 experimentally infected oysters allowed us to develop a protocol of horizontal transmission through cohabitation trials. It was demonstrated that healthy oysters after 2 days of cohabitation with experimentally infected oysters develop the disease. Thus, our previous results contributed to the set up of a reproducible model for studying the pathogenicity of OsHV-1 on C. gigas oysters in experimental conditions. 
In this context, the aim of the present study was to investigate the kinetic of OsHV-1 DNA detection in the Pacific oyster $C$. gigas in cohabitation assays between healthy and experimentally infected oysters. The experiment was conducted in a closed system without the seawater being changed. Virus DNA quantification was performed by real-time quantitative PCR (qPCR) in the time course of the experiment in different oyster tissues including haemocytes, gills, mantle, adductor muscle, and digestive gland. Besides, very little information is available concerning the detection of the virus in seawater. Thus, virus DNA amounts were also measured in seawater during the time course of the present experiment.

\section{Materials and methods}

\subsection{Oysters}

One-year-old cupped Pacific oysters C. gigas were purchased in November 2008 from a shellfish farm located on the French Mediterranean coast. Animal size was around $40 \mathrm{~mm}$ in length, $5 \mathrm{~g}$ of total weight. Animals did not present any mortality or other symptom of disease prior the experiment. Moreover, no abnormal mortality event has been reported at the shellfish farm location in 2008. Oysters were placed in the Ifremer's facilities (Laboratoire de Génétique et Pathologie, La Tremblade, France) in a single tank of $200 \mathrm{~L}$ of filtered $(1 \mu \mathrm{m})$ seawater and slowly acclimated to $22^{\circ} \mathrm{C}$ increasing the temperature of $1{ }^{\circ} \mathrm{C} /$ day. During this period, oysters were fed everyday by addition of 2 liters of microalgae Skeletonema costatum $\left(1.5 \times 10^{3} \mathrm{cells} / \mathrm{mL}\right)$. At the end of the acclimatization period and just before the beginning of the experiment, a set of 14 individuals was assessed by real-time quantitative PCR (qPCR) in order to evaluate initial OsHV-1 prevalence.

\subsection{Design for experimental OsHV-1 infection}

A pool of 120 oysters was predestined to be used as virus source of infection for the establishment of the experimental protocol of horizontal virus transmission in a closed system. These oysters were placed out of water for 24 hours at $22^{\circ} \mathrm{C}$ and then anesthetized by being placed during 4 hours at $22^{\circ} \mathrm{C}$ in a solution of seawater $(1 \mathrm{v}) /$ distilled water $(4 \mathrm{v})$ containing $7 \%(\mathrm{w} / \mathrm{v})$ of magnesium chloride $\left(\mathrm{MgCl}_{2} ; 50 \mathrm{~g} \mathrm{~L}^{-1}\right)$. Once a time relaxed, $100 \mu \mathrm{L}$ of a fresh OsHV-1 suspension at $1.5 \times 10^{5}$ viral DNA copies $\mu \mathrm{L}^{-1}$, were injected into the adductor muscle of each animal (Schikorski et al, submitted). OsHV-1 ( $\mu$ Var genotype; Segarra et al, in press) suspension was prepared from naturally infected oysters collected on the field during the summer 2008 . Inoculated oysters were then placed for 48 hours at $22^{\circ} \mathrm{C}$ in $5 \mathrm{~L}$ tanks supplied in filtered $(1 \mu \mathrm{m})$ seawater without food supply nor seawater change. After 48 hours, these oysters were used as source of virus to infect healthy oysters by horizontal transmission of OsHV-1.

Three hundred healthy individuals were randomly distributed in three aquaria supplied with $25 \mathrm{~L}$ of filtered $(1 \mu \mathrm{m})$ seawater at $22^{\circ} \mathrm{C}$. Forty moribund oysters, experimentally infected as described above, were placed in a basket added in the center of each aquarium. Two negative controls were included in the experimental design. The first one consisted of 100 healthy oysters in contact with 40 healthy oysters sacrificed by removing the superior valve. The second one consisted of 100 healthy oysters alone. After 48 hours of cohabitation, the different baskets containing infected or healthy oysters were removed. Experimentally infected oysters and healthy animals were maintained in a closed system without the seawater being changed during the time course of the experiment in order to increase the virus transmission.

In order to evaluate the kinetic of virus DNA detection, a pool of 10 live oysters from each aquarium was sacrificed at $0,6,24,30,48,72,96,120$, and 144 hours. The haemolymph of each animal was first collected from the adductor muscle, using a $1 \mathrm{~mL}$ syringe fitted with a $20 \mathrm{G}$ needle. Haemolymphs were pooled for each tank (10 oysters per tank) at each collecting time and then haemocytes were collected by centrifugation (1500 x g for $10 \mathrm{~min}$, $4^{\circ} \mathrm{C}$ ). After haemolymph collection, the upper valve of sampled animals was removed and 
tissue fragments of approximately $25 \mathrm{mg}$ were dissected from gills, mantle, adductor muscle, and digestive gland. To prevent an external contamination of these samples by virus particles present in seawater, tissue samples were rinsed three times in autoclaved artificial seawater filtered through $0.22 \mu \mathrm{m}$ filters. Tissue samples were pooled together for each tank at each collecting time (10 oysters per tank). Haemocytes and tissue samples were frozen in liquid nitrogen, and stored at $-80^{\circ} \mathrm{C}$ until DNA extraction. During the time course of the experiment, aquaria were checked daily and dead oysters were removed from tanks.

Detection of viral DNA in the seawater was also evaluated. Since the beginning of the cohabitation period, $1 \mathrm{~mL}$ of seawater was sampled in each aquarium at $0,6,24,30,48,54$, $72,78,96,102,120,144$, and 168 hours. Samples of seawater were stored at $-20^{\circ} \mathrm{C}$ until DNA extraction and qPCR analysis.

Finally, three other aquaria containing each 25 oysters in contact with 10 moribund oysters (experimentally infected as above) and supplied with $6 \mathrm{~L}$ of filtered $(1 \mu \mathrm{m})$ seawater at $22^{\circ} \mathrm{C}$ were exclusively devoted to the monitoring of mortalities occurring during the cohabitation experiment.

\subsection{DNA extraction from oyster tissue and seawater samples}

Total DNA was extracted from oyster tissues or seawater samples using the QIAgen QIAamp tissue mini kit combined with the use of the QIAcube automate according to the manufacturer's protocol. Briefly, tissue samples were digested overnight on a rocking platform at $56^{\circ} \mathrm{C}$ by addition of $180 \mu \mathrm{L}$ of ATL buffer supplied with $20 \mu \mathrm{L}$ of proteinase $\mathrm{K}$ per $25 \mathrm{mg}$ of sample. When tissues were completely lysed, a volume of $200 \mu \mathrm{L}$ of lysate was transferred into a $2 \mathrm{~mL}$ microcentrifuge tube and DNA extraction with QIAamp Mini spin columns was carried out using a QIAcube automate. Final elution of DNA extracted from tissue samples was performed with $200 \mu \mathrm{L}$ of double-distilled water.

For seawater samples, DNA was extracted from $200 \mu \mathrm{L}$ of samples previously treated on a rocking platform at $56^{\circ} \mathrm{C}$ during $1 \mathrm{~h}$ after addition of $180 \mu \mathrm{L}$ of lysis buffer supplied with $20 \mu \mathrm{L}$ of proteinase K. DNA extractions were performed manually with a final elution of $50 \mu \mathrm{L}$ of double-distilled water.

DNA concentrations and DNA quality were measured using a spectrophotometer Eppendorf, then stored at $-20^{\circ} \mathrm{C}$ prior OsHV-1 detection and quantification by qPCR.

\subsection{OsHV-1 DNA quantification by qPCR}

The detection and quantification of OsHV-1 DNA was carried out using the real-time PCR protocol previously published (Pepin et al., 2008). After dilution to $2 \mathrm{ng} \mu \mathrm{L}^{-1}, 5 \mu \mathrm{L}$ of DNA samples were added to the reaction mix composed of $12.5 \mu \mathrm{L}$ of Brillant ${ }^{\circledR}$ SYBR Green Master Mix reagent (Stratagene), $2.5 \mu \mathrm{L}$ of both $\mathrm{C} 9$ forward and $\mathrm{C} 10$ reverse primers diluted at the concentration of $2 \mu \mathrm{M}$ each, and $2.5 \mu \mathrm{L}$ of distilled water (Barbosa-Solomieu et al., 2004). All amplification reactions were performed using a Mx3000P real-time PCR thermocycler sequence detector (Stratagene) with 96-microwell plates according to the following conditions: 1 cycle of pre-incubation at $95^{\circ} \mathrm{C}$ for $10 \mathrm{~min} ; 40$ cycles of amplification at 95 for $30 \mathrm{~s}, 60^{\circ} \mathrm{C}$ for $1 \mathrm{~min}$, and $72^{\circ} \mathrm{C}$ for $1 \mathrm{~min}$; and a final step for melting temperature curve analysis at $95^{\circ} \mathrm{C}$ for $1 \mathrm{~min}, 60^{\circ} \mathrm{C}$ for $30 \mathrm{~s}$, and $95^{\circ} \mathrm{C}$ for $30 \mathrm{~s}$. The specificity of the PCR products was systematically checked with the melting temperature value calculated from the dissociation curve (Bustin, 2000). Absolute quantification of OsHV-1 DNA copies was carried out by comparing CT values obtained for tested samples with the standard curve based on a ten-fold dilution curve derived from a stock solution of OsHV-1 genomic DNA ( $5 \times 10^{6}$ copies $\mu^{-1}$ ) extracted from purified virus particles (Le Deuff and Renault, 1999). Efficiency (E) and linearity $\left(R^{2}\right)$ were calculated from the standard curve with MxPro v3.0 software (Stratagene), and tested for each run. All samples were analyzed in triplicate. The results were expressed as a $\log ^{10}$ of the viral DNA copy number per ng of tissue or per $\mu \mathrm{L}$ of seawater. 


\subsection{Statistical analysis}

Statistical analyses of the viral DNA quantification in seawater and tissues samples were carried out using the XLSTAT-Pro ${ }^{\circledR}$ v7.5.3 software. The normality of the data was tested using a Shapiro-Wilk test. A non-parametric Kruskal-Wallis test followed by a Dunn post hoc comparison test was performed to compare differences between means of viral DNA amounts quantified in oyster tissues and seawater during the time course of the experiment. Finally, Spearman rho tests were used to analyze correlations between viral DNA amounts quantified in the different oyster tissues and mortality monitored during cohabitation, and also between the different oyster tissues themselves. A P-values level of 0.05 was used in all tests to identify significant effects or differences.

\section{Results}

\subsection{Oyster mortality}

Batches of oysters infected by intramuscular injection of OsHV-1 suspensions were characterized by a sudden mortality (around $55 \%$ ) occurring only 2 days after injection (Fig. 1). At Day 6 post-injection, the cumulative mortality was around $80 \%$ and reach $90 \%$ at the end of the experiment (Day 10).

Mortalities rates observed in batches of oysters cohabited with moribund oysters were significantly lower than those recorded in oysters infected by intramuscular injection $(P<0.001)$. Mortality rates increased gradually from Day 1 to Day 8 and reached a maximum at $50 \%$ at Day 10. No mortality was observed in both negative controls.

\subsection{Quantification of OsHV-1 DNA in seawater samples}

The kinetic of OsHV-1 DNA detection was monitored by qPCR in seawater during the experiment. No virus DNA was detected in seawater samples at T0. Six hours after addition of oysters experimentally infected by OsHV-1 per intramuscular injection, the amount of virus DNA in seawater increased to reach $1 \times 10^{2}$ DNA copies/ $\mu \mathrm{L}$ and remained stable up to $48 \mathrm{~h}$ (Fig. 2). No statistical differences were evidenced between the three different tanks from $6 \mathrm{~h}$ to $48 \mathrm{~h}$. After $54 \mathrm{~h}$, once that intramuscularly injected oysters were removed, the amount of viral DNA decreased slightly as approximately $2.46 \times 10^{1}$ DNA copies/ $\mu \mathrm{L}$ (Fig. 2). Then, the number of viral DNA copies in seawater increased again at $72 \mathrm{~h}$ with a maximal significant amount of viral DNA of $1 \times 10^{3}$ DNA copies/ $\mu \mathrm{L}$ detected at $102 \mathrm{~h}(P=0.033)$ (Fig. 2). Finally, results revealed a last phase of decrease of the mean number of OsHV-1 DNA copies in seawater from $120 \mathrm{~h}$ to $168 \mathrm{~h}$, where the amount of viral DNA appeared less than $1 \times 10^{1}$ DNA copies/ $\mu \mathrm{L}$. No virus DNA was detected in seawater sampled in both negative controls all along the experiment (data not shown).

\subsection{Viral DNA quantification in oyster tissues}

After the acclimatization of animals in Ifremer's rearing facilities and just before starting the experiment, the initial status of OsHV-1 DNA detection was defined. For this purpose, pieces of mantle were collected from 14 individuals corresponding to more than $2.3 \%$ of the total population of oysters used for the experiment. Results of qPCR analyses did not allow to detect OsHV-1 DNA (Table 1).

The quantification of OsHV-1 DNA was also carried out in oysters intramuscularly injected with OsHV-1 suspension and used during the cohabitation experiment. Of 14 individuals analyzed, corresponding approximately to $10 \%$ of injected animals, virus DNA amounts ranged from $9.20 \times 10^{3}$ to $3.96 \times 10^{5}$ DNA copies $\mathrm{ng}^{-1}$ of total DNA extracted from tissues, 
with an mean virus DNA amount estimated to $1.37 \times 10^{5}$ DNA copies $\mathrm{ng}^{-1}$ of total DNA extracted from tissues.

The quantification of viral DNA was also assessed in different tissues sampled from oysters having cohabitated with moribund experimentally infected oysters. The kinetic of virus DNA detection was similar between adductor muscle, mantle, gills, and hemocytes (Fig. 3). For all sampling times, each tissue displayed positive results. After $6 \mathrm{~h}$ of cohabitation, the highest mean viral DNA amount was observed in hemocytes with $1.93 \times 10^{2}$ viral DNA copies $\mathrm{ng}^{-1}$ of total DNA extracted from tissues. For other organs, values were significantly lower $(P=0.025)$. Means of virus DNA amounts were $1.40 \times 10^{1}$ and $2.73 \times 10^{1}$ for adductor muscle and digestive gland, respectively. Mean values reported for gills and mantle were below $1 \mathrm{x}$ $10^{-1}$ viral DNA copies $\mathrm{ng}^{-1}$ of total DNA extracted from tissues. Until Day 2, virus DNA amounts remained stable in the different tissues. A significant increase of the virus DNA amount was then observed from $72 \mathrm{~h}$ to $96 \mathrm{~h}$ post-cohabitation in all analyzed tissues $(P \leq 0.037)$, except for the digestive gland for which the number of viral DNA copies did not show any significant difference during the rest of the experiment (Fig. 3). The highest virus DNA amounts were obtained at $96 \mathrm{~h}$ post-cohabitation and were assessed to $4.66 \times 10^{4}$, $1.27 \times 10^{5}, 1.23 \times 10^{5}$ and $3.38 \times 10^{5}$ DNA copies $\mathrm{ng}^{-1}$ of total DNA extracted from tissues in hemocytes, gills, mantle and adductor muscle, respectively (Fig. 3). These virus DNA amounts were not significantly different between analyzed tissues $(P=0.622)$. For longer period of cohabitation, results of qPCR analysis showed a significant decline of virus DNA amounts in each type of tissue (Fig. 3).

The quantification of virus DNA was performed in the different pooled tissues of oysters corresponding to negative controls at $48 \mathrm{~h}$ and $96 \mathrm{~h}$. Results did not show virus DNA above 1 $x 10^{1}$ DNA copies $\mathrm{ng}^{-1}$ of total DNA extracted from tissues. A significant correlation was evidenced between mortality recorded during cohabitation and viral DNA amounts quantified in different oyster tissues, including hemocytes $(\rho=0.574 ; P=0.007)$, gills $(\rho=0.598 ; P=0.004)$, mantle $(\rho=0.672 ; P<0.001)$ and adductor muscle $(\rho=0.712 ; P<0.001)$. No correlation was notified regarding the digestive gland.

\section{Discussion}

Previous studies have led to hypothesize ways of OsHV-1 transmission in the Pacific oyster Crassostrea gigas. It has been notably suggested that asymptomatic OsHV-1 infected oysters may play a role of reservoirs of the virus and that seawater may act as a vector in the horizontal transmission of OsHV-1 (Arzul et al., 2002; Le Deuff et al., 1996). Although experimental OsHV-1 infections has been carried out successfully in C. gigas at larval stages (Le Deuff et al., 1994, 1996), attempts to reproduce the disease in oyster spat have been inconclusive until 2008. A first experimental data set indicated that it was possible to transmit OsHV-1 to C. gigas spat, in cohabitation experiments using live infected larvae. A 40\% mortality rate of challenged spat was only observed when the spat were kept in stressful conditions. In those experiments, control mock-challenged spat presented a mortality rate of 20\% (Renault, unpublished data). However, when holding conditions were improved, so reducing the stress levels of the animals, no significant mortalities were observed. In 2008, a protocol based on intramuscular injection of viral suspensions prepared from naturally infected fresh oysters, collected during mortality outbreaks occurring in the field during the summer period, allowed to reproduce the viral disease in C. gigas spat in experimental conditions (Schikorski et al, submitted). The availability of OsHV-1 experimentally infected oysters allowed us to design an experimental approach which permits to mimic infections occurring in natural conditions on the field. The kinetic of OsHV-1 DNA detection in oyster tissues and seawater was then investigated in experimental conditions.

In the present experiment, oysters experimentally infected by intramuscular injection of OsHV-1 suspension served as the source of infective virus particles. Mortality recorded in these infected oysters reached approximately $80 \% 4$ days post-injection, confirming the 
reproducibility of the experimental infection protocol developed in 2008 (Schikorski et al., submitted). An interval of 2 days seems to be necessary between injection and the outbreak of mortality. This period may reflect the incubation period required for the virus to initiate an intense replication phase leading to irreversible cell damages and oyster mortality, as previously suggested by Sauvage et al. (2009). The injected oysters do seem to have become infected with OsHV-1 and when they were cohabited with healthy oysters the latter became infected. Interestingly, mortality rates recorded in initially healthy oysters during the cohabitation experiment were lower and required a longer period (50\% of mortality after 8 days). This longer period could be related to the time needed by the virus to be convoyed in seawater to attain naïve individuals and to infect them by natural means, which is more representative of what happens in natural conditions. Once again, these results corroborate suppositions made by Sauvage et al. (2009) suggesting that OsHV-1 outbreaks observed in the field could takes place during a mean period of 10 days which could correspond to the required time for the transmission of the virus and the development of the disease in favorable temperature conditions. In our study, experimental assays were performed at $22^{\circ} \mathrm{C}$, a temperature reported in the field during the summer period and currently associated with the development of OsHV-1 infections (Soletchnik et al., 1998).

Furthermore, differences in cumulative mortality rates between injected animals and cohabited animals - 90\% versus $50 \%$ - could be first explained by the different routes of infection. Unlike the injection protocol consisting to infect directly oysters by injection of the infective virus suspension in the adductor muscle, we could suppose that some oysters could be not contaminated by the virus in the case of cohabitation and interpreted as being not to have been infected. Moreover, results may suggest that effective infection also depended of the quantity of virus particles in contact with oysters. The quantity of estimated virus particles injected based on virus DNA quantification was around $1.5 \times 10^{7}$ DNA copies per oyster. As the mean quantity of virus particles detected in seawater was $1 \times 10^{2}$ DNA copies $\mu l^{-1} 6$ hours after adding experimentally infected oysters, we can assume that the maximal quantity of virus particles was $2.5 \times 10^{9}$ in each tank. Thus, the amount of virus particles available for each oyster (100 per tank) at a particular time may be estimated at $2.5 \times 10^{7}$. This quantity is comparable to the virus particle amount injected in oysters $\left(1.5 \times 10^{7} \mathrm{DNA}\right)$. Moreover, on the assumption that juvenile oysters $(40 \mathrm{~mm})$ would be able to filter a mean of $0.5 \mathrm{~L}$ of seawater/h (Bougrier et al., 1995), an oyster would then filtrate approximately $5 \times 10^{7}$ equiv. virus particles/h. Consequently, a competition may exist between oysters in term of accumulation of virus particles. In this context, a relationship between filtration activity and susceptibility to the viral disease may be suspected. However, it is necessary to keep in mind that qPCR used to quantify OsHV-1 DNA did not specify whether copies of viral DNA corresponded to infective viruses (enveloped virus particles), which are necessary to initiate the viral infection in host-cells (Lyman and Enquist, 2009). The presumption of the existence of genetic basis for resistance to OsHV-1 infections could also explain that some oyster spat survived at the end of our experiment, and that whether in the case of cohabitation (50 \% after 10 days) or intramuscular injection protocols (10\% after 10 days). These observations could be attributed to the presence of better immunological and physiological capacities in some animals, which reduce their susceptibility against the development of the disease. Furthermore, we could also suggest that epithelial surfaces could act as physical barrier in horizontal routes of infection, activating innate immunity response that intramuscular route could bypass.

Molecular techniques have been developed to detect OsHV-1 in infected oysters (Arzul et al., 2002; Le Deuff et al., 1995; Lipart and Renault, 2002; Renault et al., 2000a; Renault and Lipart, 1998). Among these methods, the qPCR quantification (Pepin et al., 2008) can be used to measure virus DNA amounts in both oyster tissues and seawater samples. In situ hybridization analysis, using specific DIG-labeled probes showed that OsHV-1 was able to infect different tissues of $C$. gigas including gills, labial palps, mantle, digestive gland, heart, adductor muscle, gonads and nervous ganglia (Lipart and Renault, 2002). Moreover, gills and mantle appeared as organs target for the viral replication and thus have been recommended for epidemiological studies (Arzul et al., 2002; Pepin et al., 2008; Sauvage et 
al., 2009). In the present study, OsHV-1 DNA was quantified in haemocytes, gills, mantle, adductor muscle, and digestive gland. OsHV-1 DNA was detected in all tissues only 6 hours after the start of the cohabitation assay. At this sampling date, the highest virus DNA amount was reported in haemocytes ( $>1 \times 10^{2}$ DNA copies $\mathrm{ng}^{-1}$ of total DNA extracted from tissues). This result may be interpreted as a rapid penetration of the virus in the haemolymphatic system and explained because of the open circulatory system present in oysters. Maximal virus DNA amounts were observed in all tissues 96 hours after the beginning of the cohabitation. Values ranging from $1 \times 10^{4}$ to $1 \times 10^{5}$ DNA copies $\mathrm{ng}^{-1}$ of total DNA extracted from tissues can be the result of virus replication in target tissues leading to irreversible cell damages and oyster mortality. Such a result has been previously reported in the mantle of infected oysters (Sauvage et al., 2009). Concerning the digestive gland, virus DNA amounts ranging from $1 \times 10^{2}$ to $1 \times 10^{3}$ copies of viral DNA ng ${ }^{-1}$ of total DNA extracted from tissue were detected early suggesting than this organ may play a role for the entry of the virus during the feeding step. However, important variations of viral DNA amounts were observed between the experimental tanks. These results can be justified by the presence of high quantity of PCR enzymatic inhibitors in the digestive gland (Kaufman et al., 2004). Although OsHV-1 has been detected in nervous tissues based on ISH (Lipart and Renault, 2002), the small size of oyster nervous ganglia, and consequently the difficulty to dissect them, did not permit to study the virus DNA quantification in such tissues.

Although no virus DNA was detected at the start of the experiment in examined healthy oysters (14 individuals), low virus DNA amounts were detected in some pools of asymptomatic oysters collected from both negative controls during the time course of the experiment. However, no mortality has been recorded in these controls. Experimental conditions might induce stress and cause virus replication at low levels in healthy carrier oysters without inducing an expressed disease. Arzul et al. (2002) have already reported the detection of virus DNA in healthy animals and suggested the existence of healthy carriers. These observations are corroborated by Pepin et al. (2008) supporting that oysters showing a virus DNA amount inferior to $1 \times 10^{1}$ DNA copies $\mathrm{ng}^{-1}$ of total DNA extracted from tissue were not associated with mortalities (Le Deuff et al., 1996; Sauvage et al., 2009). In our study, such low virus DNA amounts were also reported in some animals still alive at the end of the experiment of cohabitation (data not shown). However, these observations do not allow us to dismiss the hypothesis that these animals could maybe develop more slowly the disease, which could lead to their death the days following the discontinuation of the experiment.

Virus DNA quantification was also performed in seawater during all the time course of the experiment. Results indicated that virus DNA was not detected at the start of the experiment and virus DNA amounts then increased rapidly to approximately $1 \times 10^{2}$ DNA copies/ $\mu \mathrm{L}$ of water $6 \mathrm{~h}$ after moribund experimentally infected oysters have been added in aquaria, and remained stable during the first 48 hours. As the experiment was conducted in a closed system, without seawater change, these results may indicate that the virus detected in oysters during the course of the experiment was not related to a virus contamination of the water supply at the start of the study. A lightly decrease of virus DNA amounts corresponding to the removing time of dead experimentally infected oysters was observed after 48 hours. Although the initial source of virus particles has been removed from aquaria, a second increase of virus DNA amounts was notified after 96 hours with maximal values at 102 hours. These results suggested that oysters were infected after cohabitation with injected oysters and leached infective virus particles which can participate to the spread of the disease.

A bacterial monitoring was also carried out during the experiment in seawater and in the haemolymph of moribund oysters (data not show). The research of pathogenic bacterial strains of Vibrio sp. known to be currently implicated in mortality outbreaks of $C$. gigas, such as Vibrio splendidus and Vibrio aesturianus, was performed by qPCR (Saulnier et al., 2009). Both no detectable Vibrio aestuarianus DNA and no significant increase in Vibrio splendidus DNA were evidenced in samples tested during cohabitation trial monitoring (data not shown), suggesting that mortalities occurring during the course of the experiment can be attributed to OsHV-1 infection alone. 
In conclusion, this work constitutes the first study on the kinetic of OsHV-1 DNA detection in experimentally infected $C$. gigas by cohabitation. Mass mortality and virus detection only occurred in oysters cohabited with injected oysters suggesting that the main source of virus was from the experimentally infected oysters. Taken together, results suggested that infective virus particles could first enter thought the digestive gland and the haemolymphatic system. In a second step, virus particles could be transported by haemolymph to the different target organs before to finally engage an intense replication phase conducting to the development of the disease in target tissues. As previously evocated by Sauvage et al. (2009), improved knowledge about the transmission of OsHV-1 may contributed to the establishment of practical precautions and epidemiological recommendations, which would contribute to reduce the impact of virus contamination of Pacific oysters. Some technical practices occurring frequently in oyster aquaculture, such as transfers of oyster batches, might represent a risk for the spread of the disease, and especially during the summer period. Indeed, at the view of present results, a short time of contact appears sufficient for virus transmission from infected oysters to healthy ones.

\section{Acknowledgements}

Authors wish to express our gratitude to M. Sallas from "CAT de Maguelone", at Palavas for providing healthy animals. We also are grateful to P. Legall from Ifremer Sète station for all care given to oysters and shipment from Prévost lagoon, and to P. Haffner for his technical assistance in bacteriology.

\section{References}

Arzul, I., Nicolas, J.-L., Davison, A.J. and Renault, T. (2001a) French scallops: A new host for Ostreid Herpesvirus-1. Virology 290(2), 342.

Arzul, I., Renault, T. and Lipart, C. (2001b) Experimental herpes-like viral infections in marine bivalves: demonstration of interspecies transmission. Diseases of Aquatic Organisms 46(1), 1

Arzul, I., Renault, T., Lipart, C. and Davison, A.J. (2001c) Evidence for interspecies transmission of oyster herpesvirus in marine bivalves. Journal of General Virology 82, 865-870.

Arzul, I., Renault, T., Thebault, A. and Gerard, A. (2002) Detection of oyster herpesvirus DNA and proteins in asymptomatic Crassostrea gigas adults. Virus Research 84(1/2), 151-160.

Barbosa-Solomieu, V., Miossec, L., Vazquez-Juarez, R., Ascencio-Valle, F. and Renault, T. (2004) Diagnosis of Ostreid herpesvirus 1 in fixed paraffin-embedded archival samples using PCR and in situ hybridisation. Journal of Virological Methods 119(2), 65.

Bougrier, S., Geairon, P., Deslous-Paoli, J.-M., Bacher, C. and Jonquières, G. (1995) Allometric relationships and effects of temperature on clearance and oxygen consumption rates of Crassostrea gigas (Thunberg). Aquaculture 134(1/2), 143-154

Bustin, S.A. (2000) Absolute quantification of mRNA using real-time reverse transcription polymerase chain reaction assays. Journal of Molecular Endocrinology 25(2), 169-93.

Chang, P.H., Kuo, S.T., Lai, S.H., Yang, H.S., Ting, Y.Y., Hsu, C.L. and Chen, H.C. (2005) Herpes-like virus infection causing mortality of cultured abalone Haliotis diversicolor supertexta in Taiwan. Diseases Of Aquatic Organisms 65, 23-27.

Comps, M. and Cochennec, N. (1993) A herpes-like virus from the European oyster Ostrea edulis L. Journal of Invertebrate Pathology 62, 201-203.

Davison, A.J. (2002) Evolution of the herpesviruses. Veterinary Microbiology 86(1/2), 69. 
Davison, A.J., Trus, B.L., Cheng, N., Steven, A., Watson, M.S., Cunningham, C., Le Deuff, R.M. and Renault, T. (2005) A novel class of herpesvirus with bivalve hosts. Journal of General Virology 86(1), 41.

Davison, A.J., Eberle, R., Ehlers, B., Hayard, G.S., McGeoch, D.J., Minson, A.M., Pellett, P.E., Roizman, B., Studdert, M.J., Thiry, E. (2009) The order Herpesvirales. Archives of Virology 154: 171-177.

Farley, C.A. Banfield, W. G., Kasnic, J. R. G., Foster, W. S. (1972) Oyster herpes-type virus. Science 178, 759-760.

Friedman, C.S., Estes, R.M., Stokes, N.A., Burge, C.A., Hargove, J.S., Barber, B.J., Elston, R.A., Burreson, E.M. and Reece, K.S. (2005) Herpes virus in juvenile Pacific oysters Crassostrea gigas from Tomales Bay, California, coincides with summer mortality episodes. Diseases of Aquatic Organisms 63(1), 33.

Hine, P.M. (1992) Ultrastructural and ultracytochemical observations on Bonamia sp. in oysters (Tiostrea chilensis ), with a consideration of organelle function. Aquaculture, 107, 2-3 vols, pp. 175-183.

Hine, P.M. and Thorne, T. (1997) Replication of herpes-like viruses in haemocytes of adult flat oysters Ostrea angasi : an ultrastructural study. Diseases of Aquatic Organisms 29, 189-196.

Hine, P.M., Wesney, B. and Besant, P. (1998) Replication of a herpes-like virus in larvae of the flat oyster Tiostrea chilensis at ambient temperatures. Diseases of Aquatic Organisms 32, 161-171.

Hooper, C., Hardy-Smith, P. and Handlinger, J. (2007) Ganglioneuritis causing high mortalities in farmed Australian abalone (Haliotis laevigata and Haliotis rubra). Australian Veterinary Journal 85 (5), 188-93.

Kaufman, G.E., Blackstone, G.M., Vickery, M.C., Bej, A.K., Bowers, J., Bowen, M.D., Meyer, R.F. and DePaola, A. (2004) Real-time PCR quantification of Vibrio parahaemolyticus in oysters using an alternative matrix. Journal of Food Protection 67 (11), 2424-2429.

Le Deuff, R.M., Nicolas, J.-L., Renault, T. and Cochennec, N. (1994) Experimental transmission of a herpes-like virus to axenic larvae of Pacific oyster, Crassostrea gigas. Bulletin of the European Association of fish Pathologists 14(2), 69-72.

Le Deuff, R.M. and Renault, T. (1999) Purification and partial genome characterization of a herpes-like virus infecting the Japanese oyster, Crassostrea gigas. The Journal of General Virology 80 ( Pt 5), 1317.

Le Deuff, R.M., Renault, T. and Cochennec, N. (1995) Antibodies specific for channel catfish virus cross-react with Pacific oyster, Crassostrea gigas, herpes-like virus. Veterinary Research 26 (5/6), 526.

Le Deuff, R.M., Renault, T. and Gérard, A. (1996) Effects of temperature on herpes-like virus detection among hatchery-reatred larval Pacific oyster Crassostrea gigas. Diseases of Aquatic Organisms 24, 149-157.

Lipart, C. and Renault, T. (2002) Herpes-like virus detection in infected Crassostrea gigas spat using DIG-labelled probes. Journal of Virological Methods 101 (1/2), 1.

Lyman, M.G. and Enquist, L.W. (2009) Herpesvirus interactions with the host cytoskeleton. Journal of Virology 83 (5), 2058-2066.

Minson, A.C., Davison, A., Eberle, R., Desrosiers, R.C., Fleckenstein, B., McGeoch, D.J., Pellet, P.E., Roizman, B. and Studdert, D.M.J. (2000) Family Herpesviridae. In: Virus Taxonomy: Classification and Nomenclature of Viruses Seventh Report of the International Commitee on Taxonomy of Viruses (Academic press, USA), 203-225.

Moss, J. A., Burreson, E. M., Cordes, J. F., Dungan, C. F., Brown, G. D., Wang, A., Wu, X and Reece, K. S. (2007). Pathogens in Crassostrea ariakensis and other Asian oyster species: implication for non-native oyster introduction to Chesapeake Bay. Dis Aquat Organ 77(3), 207-23.

Nicolas, J.-L., Comps, M. and Cochennec, N. (1992) Herpes-like virus infecting Pacific-oyster larvae, Creassostrea gigas. Bulletin of the European Association of fish Pathologists 12(1), 11-13. 
Olicard, C., Didier, Y., Marty, C., Bourgougnon, N. and Renault, T. (2005a) In vitro research of anti-HSV-1 activity in different extracts from Pacific oysters Crassostrea gigas. Diseases of Aquatic Organisms 67 (1/2), 141-147.

Olicard, C., Renault, T., Torhy, C., Benmansour, A. and Bourgougnon, N. (2005b) Putative antiviral activity in hemolymph from adult Pacific oysters, Crassostrea gigas. Antiviral Research 66 (2/3), 152.

Pepin, J.F., Riou, A. and Renault, T. (2008) Rapid and sensitive detection of Ostreid herpesvirus 1 in oyster samples by real-time PCR. Journal of Virological Methods 149(2), 269-276.

Renault, T. (1998) Infections herpétiques chez les invertébrés : détection de virus de type herpès chez les mollusques bivalves marins. Virologie 2(5), 401-403.

Renault, T. and Arzul, I. (2001) Herpes-like virus infections in hatchery-reared bivalve larvae in Europe: specific viral DNA detection by PCR. Journal of Fish Diseases 24 (3), 161.

Renault, T., Cochennec, N., Le Deuff, R.M. and Chollet, B. (1994) Herpes-like virus infecting Japanese oyster (Crassostrea gigas) spat. Bulletin of the European Association of fish Pathologists 14 (2), 64-66.

Renault, T., Le Deuff, R.-M., Lipart, C. and Delsert, C. (2000a) Development of a PCR procedure for the detection of a herpes-like virus infecting oysters in France. Journal of Virological Methods 88 (1), 41.

Renault, T., Le Deuff, R.M., Chollet, B., Cochennec, N. and Gerard, A. (2000b) Concomitant herpes-like virus infections in hatchery-reared larvae and nursery-cultured spat Crassostrea gigas and Ostrea edulis. Diseases of Aquatic Organisms 42 (3), 173.

Renault, T., Le Deuff, R.M., Cochennec, N., Chollet, B. and Maffart, P. (1995) Herpes-like viruses associated with high mortality levels in larvae and spat of Pacific oysters, Crassostrea gigas: a comparative study, the thermal effects on virus detection in hatchery-reared larvae, reproduction of the disease in axenic larvae. Veterinary Research 26 (5/6), 539.

Renault, T. and Lipart, C. (1998) Diagnosis of Herpes-like Virus Infections in Oysters Using Molecular Techniques. European Aquaculture Society. Vol. Special publication no. 26.

Renault, T., Lipart, C. and Arzul, I. (2001) A herpes-like virus infects a non-ostreid bivalve species: virus replication in Ruditapes philippinarum larvae. Diseases of Aquatic Organisms 45 (1), 1.

Renault, T. and Novoa, B. (2004) Viruses infecting bivalve molluscs. Aquatic Living Resources 17 (4), 397.

Saulnier, D., De Decker, S. and Haffner, P. (2009) Real-time PCR assay for rapid detection and quantification of Vibrio aestuarianus in oyster and seawater: a useful tool for epidemiologic studies. Journal of Microbiological Methods 77 (2), 191-197.

Sauvage, C., Pepin, J.F., Lapegue, S., Boudry, P. and Renault, T. (2009) Ostreid herpes virus 1 infection in families of the Pacific oyster, Crassostrea gigas, during a summer mortality outbreak: differences in viral DNA detection and quantification using realtime PCR. Virus Research 142 (1/2), 181-7.

Segarra, A., Pépin, J. F., Arzul, I., Morga, B., Faury, N., Renault T. (2010). Detection and description of a particular Ostreid herpesvirus 1 genotype associated with massive mortality outbreaks of Pacific oysters, Crassostrea gigas, in France in 2008, in press.

Soletchnik, P., Faury, N., Razet, D., Goulletquer, P. (1998) Hydrobiology of the MarennesOleron Bay. Seasonal indices and analysis of trends from 1978 to 1995. Hydrobiologia 386, 131-46.

Tan, J., Lancaster, M., Hyatt, A., van Driel, R., Wong, F. and Warner, S. (2008) Purification of a herpes-like virus from abalone (Haliotis spp.) with ganglioneuritis and detection by transmission electron microscopy. Journal of Virological Methods 149 (2), 338341.

Vasquez-Yeomans, R., Caceres-martinez, J. and Figueras Huerta, A. (2004) Herpes-like virus associated with eroded gills of the Pacific oyster Crassostrea gigas in Mexico. Journal of Shellfish Research 23, 417-419. 
Tables

\begin{tabular}{|llllll|}
\hline Status & Origin of animals & $\begin{array}{l}\text { Number of } \\
\text { individuals } \\
\text { analysed }\end{array}$ & $\begin{array}{l}\text { Minimal } \\
\text { individual } \\
\text { viral load }\end{array}$ & $\begin{array}{l}\text { Maximal } \\
\text { individual } \\
\text { viral load }\end{array}$ & $\begin{array}{l}\text { Average } \\
\text { viral load }\end{array}$ \\
\hline $\begin{array}{l}\text { Initial portage of OsHV-1 in } \\
\text { animals used in this study }\end{array}$ & $\begin{array}{l}\text { Prevost pond } \\
\text { France }\end{array}$ & 14 & 0 & 0 & 0 \\
$\begin{array}{l}\text { Dead individuals 2 days after } \\
\text { intramuscular injection of the } \\
\text { viral suspension of OsHV-1 }\end{array}$ & $\begin{array}{l}\text { Prevost ponsters } \\
\text { France }\end{array}$ & 14 & No Ct & No Ct & \\
\hline
\end{tabular}

Tableau 1: Real-time PCR quantification of OsHV-1 DNA in the mantle of healthy oysters collected prior the beginning of the experiment and in oysters dead 2 days after intramuscular injection of viral suspension (expressed as viral DNA copy number $\mathrm{ng}^{-1}$ of total DNA extracted from tissues samples). 


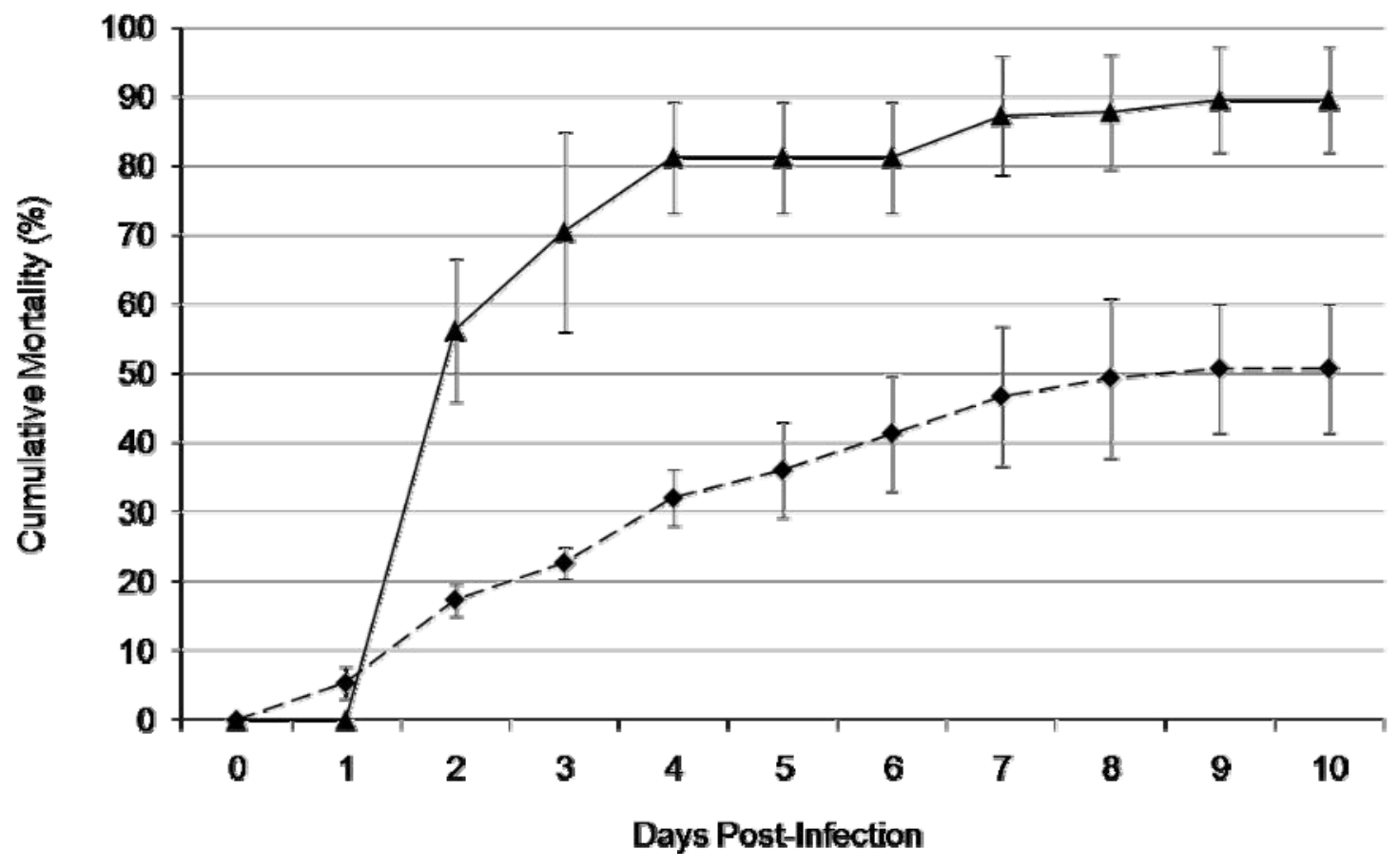

Figure 1: Mean cumulative mortality of Pacific oysters Crassostrea gigas experimentally infected by OsHV-1 either after intramuscular injection of a fresh viral suspension (straight line) or after 2 days of cohabitation with experimentally infected oysters in the case of the horizontal transmission protocol (dashed line). Results are represented as the percentage of mean cumulative mortality $\pm \operatorname{SD}(n=3)$.

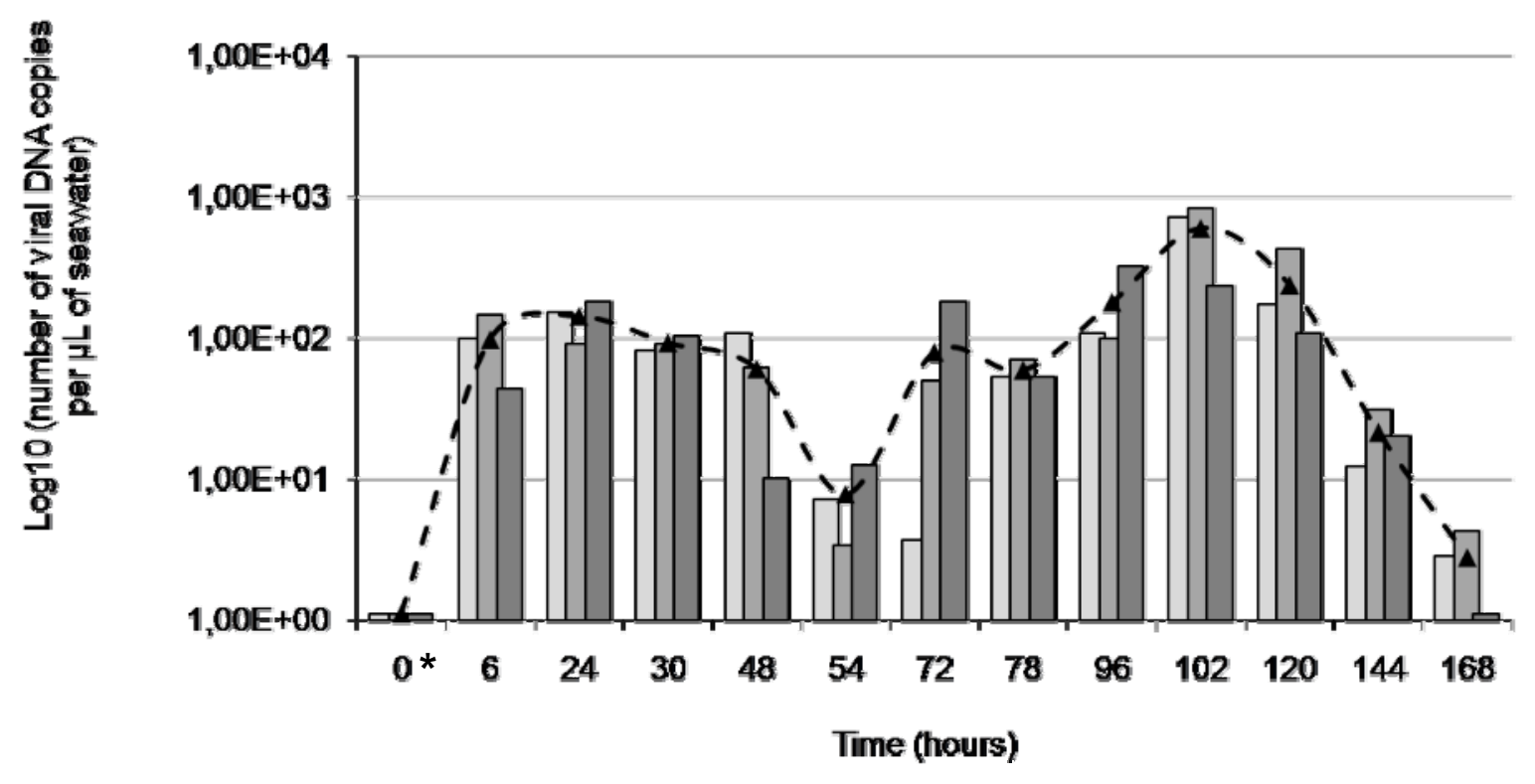


Figure 2: Kinetic of OsHV-1 DNA detection in seawater. Virus DNA amounts were quantified by real-time quantitative PCR. Results are expressed as viral DNA copy number/ $\mu \mathrm{L}$ of seawater. Data obtained from the 3 different experimental tanks are represented. *: No virus DNA was detected at time 0
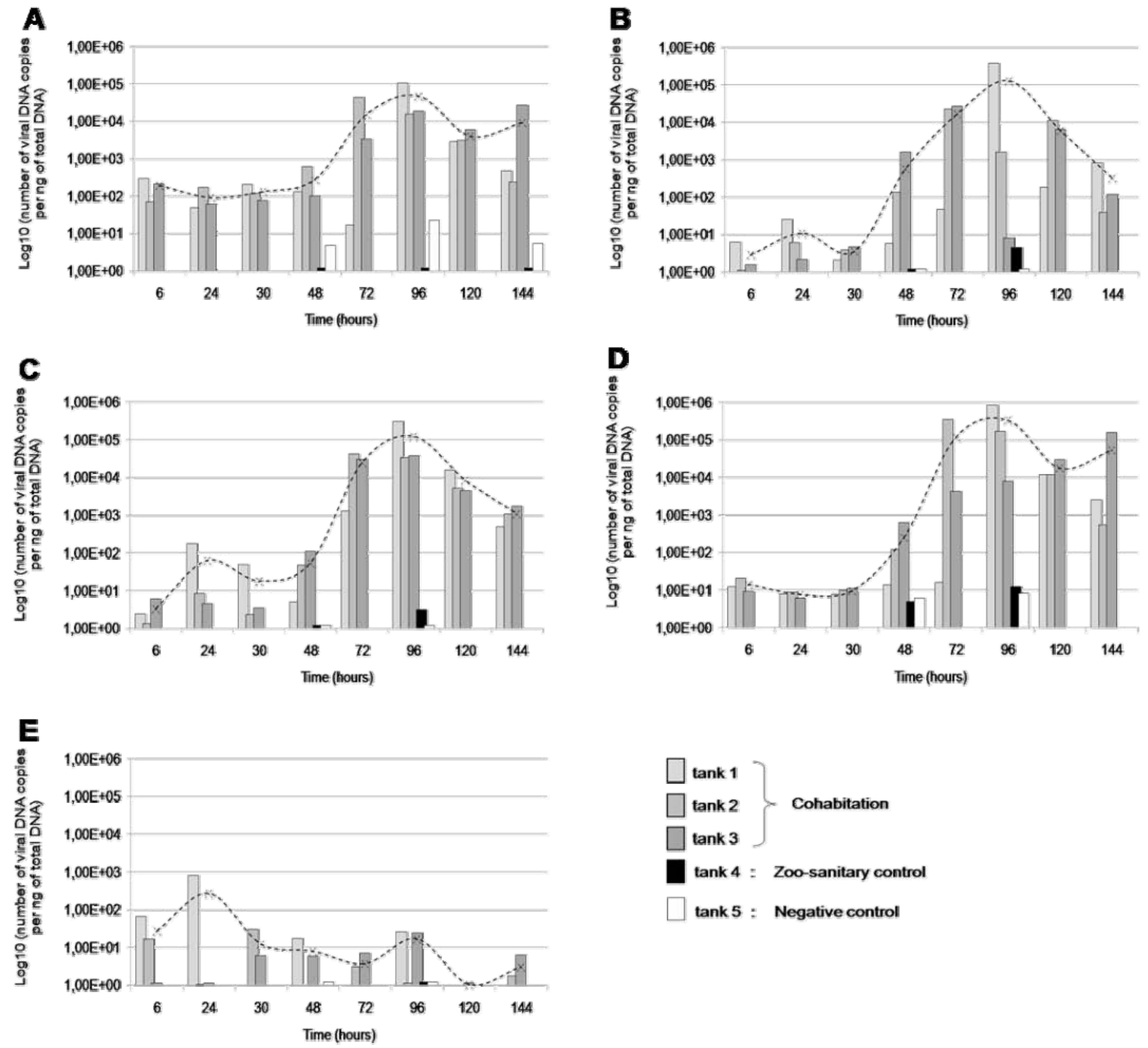

Figure 3: Kinetics of virus DNA detection in different tissues of Crassostrea gigas Pacific oyster spat after cohabitation with experimentally OsHV-1 infected oyster spat. Virus DNA amounts were quantified by real-time quantitative PCR in haemocytes (A), gills (B), mantle (C), adductor muscle (D) and digestive gland $(E)$. Results are expressed as viral DNA copy number/ng of total DNA extracted from tissues samples. The black lines represent the average kinetic of OsHV-1 DNA detection in different oyster tissues during cohabitation with moribund oysters. Data obtained from the 3 different experimental tanks are represented. 